\title{
Retrospective Study of Self Esteem in Patients with Pityriasis Versicolor
}

\author{
Bagus Meurah Suropati ${ }^{1}$, Eko Budi Koendhori ${ }^{1}$, Sawitri², Evy Ervianti ${ }^{2}$ \\ ${ }^{I}$ Department of Clinical Microbiology, Faculty of Medicine, Universitas Airlangga/Dr. Soetomo \\ General Academic Teaching Hospital Surabaya, Indonesia \\ ${ }^{2}$ Department of Dermatology and venereology, Faculty of Medicine, Universitas Airlangga/Dr. \\ Soetomo General Academic Teaching Hospital Surabaya, Indonesia
}

\begin{abstract}
Background: Pityriasis Versicolor (PV) is a fungal infection of the skin, caused by the Malassezia sp., a genus of fungi. Patients commonly present with bordered skin patches of white, grey, and sometimes brown on their skin surface. The prominent changing of skin colour in exposed areas of the skin may cause feelings of insecurity to the patients and become limelight for other people, impacting their self esteem. Purpose: To evaluate the self esteem profile in PV patients at the dermatovenereology outpatient clinic of Dr. Soetomo General Academic Teaching Hospital Surabaya. Methods: This was a retrospective descriptive study based on medical records of the dermatovenereology outpatient clinic of Dr. Soetomo General Academic Teaching Hospital Surabaya. The data were collected from June 2018 to May 2019. This research evaluates PV patients's profiles by age, sex, education level, occupation, residential environment, site of infection, duration of the infection, and self esteem. The patient's self esteem was assessed using the Rosenberg Self Esteem Scale (RSES). Result: Fiftythree PV patient's self esteem values were successfully recorded. Of the 53 patients, the score was low in 3 people (5.67\%), the normal score in 50 people (94.33\%), and no one had a high score. Of the 3 people with low self esteem scores, 2 of them were men, consisting of 1 teenager and 2 adults, having basic education levels, who were students and housewives. The three patients had the infection for more than 3 months and they resided in Tambaksari, Wonocolo, and outside Surabaya. Conclusion: The majority of PV patients at the dermato-venereology outpatient clinic of Dr. Soetomo General Academic Teaching Hospital have normal self esteem scores.
\end{abstract}

Keywords: pityriasis versicolor, self esteem, Malassezia sp.

Correspondence: Evy Ervianti, Department of Dermatology and Venereology, Faculty of Medicine Universitas Airlangga/ Dr. Soetomo General Academic Teaching Hospital, Jl. Mayjen Prof. Dr. Moestopo No. 6-8 Surabaya 60132, Indonesia. Phone: +6281332681513, email: evy_if@yahoo.co.id.

\section{BACKGROUND}

Pityriasis Versicolor (PV) is an infectious disease of the skin. It is caused by Malassezia, a species of fungi. Clinically, PV occurs as white, grey, copper red, brown, or brown-black patches with clear border on the skin. This infection can affect any skin surface depending on the skin moisture and hygiene. ${ }^{1}$

Pityriasis Versicolor typically occurs on moist skin. The surface of human skin directly interacts with the outside world; therefore, the environmental factor plays a role in PV. Data from Dr. Soetomo General Academic Teaching Hospital, Surabaya, suggested that $\mathrm{PV}$ is the second most common fungal skin infection with a high number of cases, reaching $28.4 \%$ of all cases. $^{1}$

A clear discoloration of uncovered skin will attract attention and therefore, impacting one's selfesteem and comfort. Selfesteem is defined as confidence in one's worth by analyzing behavior suitability with personal ideals. ${ }^{2}$ In Indonesia, PV is often seen as something "embarrassing" instead of a mere disease, causing most PV patients to attempt to cover the infection. In a study by Masliah (2016), it is said that leprosy has an identical clinical appearance with PV and the subjects in the reported study had minimum knowledge on leprosy and regarded it as a food induced disease, worsened by the negative stigma that regards leprosy (similar to PV) as a highly contagious and feared disease. ${ }^{3}$

In a study on psoriasis lesion by Lakuta (2017), it was inferred that skin lesion would leave stigma and stigmatization is the strongest predictor for depression symptoms for psoriatic patients. ${ }^{4}$ Szepietowski and Reich (2009) stated that patients with fungal skin infection have low self esteem, they feel embarrassment, are less encouraged to take part in social activities, and have a fear of transmitting their infection to others. ${ }^{5}$ Oftentimes, PV also leads to negative stigma, causing embarrassment and discomfort, hence the need to evaluate the patient's self-esteem to perfect the modality for PV treatment. More than physical illness, psychological disturbance should be treated as well.

\section{METHODS}

This was a retrospective descriptive study aimed 
to evaluate the selfesteem profile of PV patients at the outpatient clinic of Dermatovenereology Department in Dr. Soetomo General Academic Teaching Hospital, Surabaya. We used the total sampling method to PV patients who came to the outpatient clinic of the Dermatovenereology Department in General Hospital Dr. Soetomo Surabaya during one year from May 2018 until April 2019. We evaluated patient's age, sex, education levels, occupation, domicile, duration of infection, site of infection, and self esteem.

Patient's self esteem was evaluated using the Rosenberg Self Esteem Scale (RSES) which is the scale for calculating person's self esteem level by asking ten statements about selfassesment. In each number, patient chooses between strongly agree, agree, disagree, and strongly disagree. The score ranges from $0-30$. Scores below 15 indicate low self esteem, 15-25 scores indicate normal self esteem, and above 25 indicate high self esteem. ${ }^{6}$

\section{RESULT}

The clinical appearance and additional examination using potassium hydroxide $(\mathrm{KOH}) 10$ $20 \% \&$ Wood's lamp in the Mycology Division of Dermatovenereology outpatient clinic in May 2018 April 2019, out of 90 newly diagnosed patients, revelated that there were only 53 eligible scores. The remaining 37 subjects were excluded because they failed to evaluate their self esteem scores in pediatric patients, negligence in evaluating the score in newly registered patients, and duplicate data.
Table 1. Self esteem score

\begin{tabular}{clc}
\hline & Category & Total, n (\%) \\
\hline $\begin{array}{c}\text { Self esteem } \\
\text { score }\end{array}$ & Low & $3(5.7)$ \\
& High & $50(94.3)$ \\
\hline & Total & $0(0)$ \\
\hline
\end{tabular}

Table 1 shows that out of $53 \mathrm{PV}$ patients, only 3 subjects $(5.7 \%)$ had low self esteem scores, 50 subjects $(94.3 \%)$ had normal scores, and none with high self esteem score. Table 2 shows that the 3 subjects $(5,7 \%)$ with low self esteem scores were $2(3.8 \%)$ males and 1 (1.9\%) female. Table 3 shows that the 3 subjects (5.7\%) with low self esteem scores were $1(1.9 \%)$ teenager and $2(3.8 \%)$ adults. Table 4 shows that the 3 subjects (5.7\%) with low self esteem scores were 1 (1.9\%) with basic education and $2(3.8 \%)$ with no data. Table 5 shows that the 3 subjects $(5.7 \%)$ with low self esteem scores were $1(1.9 \%)$ student/college student, 1 (1.9\%) housewife, and $1(1.9 \%)$ with no data.

Table 2. Self esteem evaluation based on sex

\begin{tabular}{|c|c|c|c|c|}
\hline \multirow{2}{*}{ Sex } & \multicolumn{3}{|c|}{ Self esteem score $(\%)$} & \multirow{2}{*}{$\begin{array}{c}\text { Total } \\
(\%)\end{array}$} \\
\hline & Low & Normal & High & \\
\hline Male & $2(3.8)$ & $30(56.6)$ & 0 & $32(60.4)$ \\
\hline Female & $1(1.9)$ & $20(37.7)$ & 0 & $21(39.6)$ \\
\hline Total & $3(5.7)$ & $50(94.3)$ & 0 & $53(100)$ \\
\hline
\end{tabular}

Table 3. Self esteem evaluation based on age

\begin{tabular}{lcccc}
\hline \multirow{2}{*}{ Age } & \multicolumn{3}{c}{ Self esteem score (\%) } & \multirow{2}{*}{ Total (\%) } \\
\cline { 2 - 4 } & Low & Normal & High & \\
\hline Children (5-10 years) & 0 & $4(7.5)$ & 0 & $4(7.5)$ \\
Teenager (11-24 years) & $1(1.9)$ & $25(47.2)$ & 0 & $26(49.1)$ \\
Adult (25-44 years) & $2(3.8)$ & $13(24.5)$ & 0 & $15(28.3)$ \\
Elderly ( $\geq$ 45 years) & 0 & $8(15.1)$ & 0 & $8(15.1)$ \\
\hline \multicolumn{1}{c}{ Total } & $3(5.7)$ & $50(94.3)$ & 0 & $53(100)$ \\
\hline
\end{tabular}

Table 4. Self esteem evaluation based on the level of education

\begin{tabular}{lcccc}
\hline \multirow{2}{*}{ Level of education } & \multicolumn{2}{c}{ Self esteem score (\%) } & \multirow{2}{*}{ Total (\%) } \\
\cline { 2 - 4 } & Low & Normal & High & \\
\hline Basic education (Primary school, Middle school) & $1(1.9)$ & $23(43.4)$ & 0 & $24(45.3)$ \\
Middle education (High school) & 0 & $3(5.7)$ & 0 & $3(5.7)$ \\
Higher education ( $>$ High school) & 0 & $8(15.1)$ & 0 & $8(15.1)$ \\
No data & $2(3.8)$ & $16(30.1)$ & 0 & $18(33.9)$ \\
\hline Total & $3(5.7)$ & $50(94.3)$ & 0 & $53(100)$ \\
\hline
\end{tabular}

Table 6 shows that the 3 subjects $(5.7 \%)$ with low self esteem scores were $1(1.9 \%)$ from Tambaksari, 1 $(1.9 \%)$ from Wonocolo, and $1(1.9 \%)$ from outside Surabaya. Table 7 shows that all subjects with low self esteem scores have been suffering from PV for more than 3 months. Table 8 shows that all subjects with low self esteem scores were affected by PV on the trunk. 
Table 5. Self esteem evaluation based on occupation

\begin{tabular}{|c|c|c|c|c|}
\hline \multirow{2}{*}{ Occupation } & \multicolumn{3}{|c|}{ Self esteem score $(\%)$} & \multirow{2}{*}{$\begin{array}{c}\text { Total } \\
(\%)\end{array}$} \\
\hline & Low & Normal & High & \\
\hline $\begin{array}{l}\text { Student/college } \\
\text { student }\end{array}$ & $\begin{array}{c}1 \\
(1.9)\end{array}$ & $\begin{array}{c}25 \\
(47.2)\end{array}$ & 0 & $\begin{array}{c}26 \\
(49.1)\end{array}$ \\
\hline $\begin{array}{l}\text { Government } \\
\text { employee }\end{array}$ & 0 & $1(1.9)$ & 0 & $1(1.9)$ \\
\hline $\begin{array}{l}\text { Private } \\
\text { employee }\end{array}$ & 0 & $5(9.4)$ & 0 & $5(9.4)$ \\
\hline Housewife & $\begin{array}{c}1 \\
(1.9)\end{array}$ & $\begin{array}{c}6 \\
(11.3)\end{array}$ & 0 & $\begin{array}{c}7 \\
(13.2)\end{array}$ \\
\hline Others & 0 & $\begin{array}{c}6 \\
(11.3)\end{array}$ & 0 & $\begin{array}{c}6 \\
(11.3)\end{array}$ \\
\hline No data & $\begin{array}{c}1 \\
(1.9) \\
\end{array}$ & $\begin{array}{c}7 \\
(13.2) \\
\end{array}$ & 0 & $\begin{array}{c}8 \\
(15.1) \\
\end{array}$ \\
\hline Total & $\begin{array}{c}3 \\
(5.7) \\
\end{array}$ & $\begin{array}{c}50 \\
(94.3)\end{array}$ & 0 & $\begin{array}{c}53 \\
(100)\end{array}$ \\
\hline
\end{tabular}

Table 6. Self esteem evaluation based on the patient's domicile

\begin{tabular}{|c|c|c|c|c|}
\hline \multirow{2}{*}{ Domicile } & \multicolumn{3}{|c|}{ Self esteem score $(\%)$} & \multirow{2}{*}{$\begin{array}{c}\text { Total } \\
(\%)\end{array}$} \\
\hline & Low & Normal & High & \\
\hline \multicolumn{5}{|l|}{ North Surabaya } \\
\hline - Krembangan & 0 & $1(1.9)$ & 0 & $1(1.9)$ \\
\hline - Kenjeran & 0 & $3(5.7)$ & 0 & $3(5.7)$ \\
\hline - Semampir & 0 & $2(3.8)$ & 0 & $2(3.8)$ \\
\hline - Bulak & 0 & $1(1.9)$ & 0 & $1(1.9)$ \\
\hline \multicolumn{5}{|l|}{ West Surabaya } \\
\hline - Asemrowo & 0 & $1(1.9)$ & 0 & $1(1.9)$ \\
\hline - Benowo & 0 & $1(1.9)$ & 0 & $1(1.9)$ \\
\hline - Tandes & 0 & $1(1.9)$ & 0 & $1(1.9)$ \\
\hline \multicolumn{5}{|l|}{ East Surabaya } \\
\hline - Gubeng & 0 & $7(13.2)$ & 0 & $\begin{array}{c}7 \\
(13.2)\end{array}$ \\
\hline - Sukolilo & 0 & $2(3.8)$ & 0 & $2(3.8)$ \\
\hline - Rungkut & 0 & $1(1.9)$ & 0 & $1(1.9)$ \\
\hline - Tambaksari & $\begin{array}{c}1 \\
(1.9)\end{array}$ & $4(7.5)$ & 0 & $5(9.4)$ \\
\hline - Mulyorejo & 0 & $1(1.9)$ & 0 & $1(1.9)$ \\
\hline \multicolumn{5}{|c|}{ Central Surabaya } \\
\hline - Tegalsari & 0 & $1(1.9)$ & 0 & $1(1.9)$ \\
\hline - Bubutan & 0 & $1(1.9)$ & 0 & $1(1.9)$ \\
\hline \multicolumn{5}{|l|}{ South Surabaya } \\
\hline - Wonokromo & 0 & $5(9.4)$ & 0 & $5(9.4)$ \\
\hline - Wonocolo & $\begin{array}{c}1 \\
(1.9)\end{array}$ & 0 & 0 & $1(1.9)$ \\
\hline Outside & 1 & 18 & 0 & 19 \\
\hline Surabaya & $(1.9)$ & (33.9) & & $(35.8)$ \\
\hline Total & $\begin{array}{c}3 \\
(5.7)\end{array}$ & $\begin{array}{c}50 \\
(94.3)\end{array}$ & 0 & $\begin{array}{c}53 \\
(100)\end{array}$ \\
\hline
\end{tabular}

Table 7. Self esteem evaluation based on the duration of infection

\begin{tabular}{lcccc}
\hline \multirow{2}{*}{ Duration } & \multicolumn{3}{c}{ Self esteem score (\%) } & Total \\
\cline { 2 - 4 } & Low & Normal & High & $(\%)$ \\
\hline 1 month & 0 & 26 & 0 & $26(49.1)$ \\
& & $(49.1)$ & & \\
2 months & 0 & $4(7.5)$ & 0 & $4(7.5)$ \\
3 months & 0 & $8(15.1)$ & 0 & $8(15.1)$ \\
$>3$ & 3 & 12 & 0 & $15(28.3)$ \\
months & $(5.7)$ & $(22.6)$ & & \\
\hline Total & 3 & 50 & 0 & $53(100)$ \\
& $(5.7)$ & $(94.3)$ & & \\
\hline
\end{tabular}

Table 8. Self esteem evaluation with the site of infection

\begin{tabular}{lcccc}
\hline \multicolumn{1}{c}{$\begin{array}{c}\text { Site of } \\
\text { Infection }\end{array}$} & \multicolumn{3}{c}{ Self esteem score (\%) } & Total \\
\cline { 2 - 4 } & Low & Normal & High & $(\%)$ \\
\hline Face & 0 & 14 & 0 & 14 \\
& & $(26.4)$ & & $(26.4)$ \\
Trunk & 3 & 23 & 0 & 26 \\
& $(5.7)$ & $(43.4)$ & & $(49.1)$ \\
Face \& trunk & 0 & 13 & 0 & 13 \\
& & $(24.5)$ & & $(24.5)$ \\
\hline Total & 3 & 50 & 0 & 53 \\
& $(5.7)$ & $(94.3)$ & & $(100)$ \\
\hline
\end{tabular}

\section{DISCUSSION}

In this study, the subject's self esteem scores were evaluated with a number of factors, age, sex, level of education, occupation, site of infection, duration of infection, and the subject's domicile. The occupation was grouped into government employees, private employees, student/college students, housewives, and others. The patient's domiciles were grouped based on each corresponding subdistrict plus outside the Surabaya area.

Table 1 shows that the majority of PV patients have normal self esteem scores, even reaching $90 \%$ of the samples. In a study by de Brito et al. (2010) stated that the psychological ability to manage one's self esteem is crucial for acceptance and adaptation to physical changes and assimilation of change to the body image. ${ }^{7}$ It inferred that the psychological ability to manage self esteem in PV patients of the outpatient clinic in General Hospital Dr. Soetomo was excellent. It was in contrast with the report by Szepietowski and Reich (2009), in which patients with cutaneous fungal infection had low self esteem, felt shame, discouraged to take part in social activities, and a fear of transmitting the infection to others. ${ }^{5}$

Table 2 shows that there were more male subjects with low self esteem than female subjects. However, this finding differed from that in a study by Nirmalasari and Masusan (2014), which stated that in general, 
women tend to have lower self esteem than men. ${ }^{8}$ This was supported by findings by Sarandria (2012), that sex indeed affects self esteem. Females concern more about acceptance in their circle, while males tend to relate them with the sense of success or failure. ${ }^{9}$ Generally, the skin lesion in PV will make the affected individuals feel different; both men and women will feel ashamed, affecting their self esteem.

Table 3 shows that the low self esteem scores were found in patients from the teenage and adult age group. This is in accordance with a report by Bos (2006), which stated that self esteem development declines during adolescence. A drastic global reduction in a teenage year is related to the storm and stress phase during adolescence, characterized by biological, cognitive, social, psychological, or academic changes. ${ }^{10}$

Table 4 suggests that the low esteem scores came from subjects with a basic level of education. This is also supported by a study by Orth et al. (2010), stating that in all ages, higher educated individuals have higher self esteem. ${ }^{11}$ A study by Hampson et al. (2016) shows that educational achievement contributes to increasing one's self regulation. ${ }^{12}$ Self regulation means selfhood process necessary in managing thoughts, feelings, encouragements, and desire from outside so that it aligns with one's goals and ideals. ${ }^{13}$ Based on this theory, it can be inferred that good self regulation promotes good self esteem.

Table 5 shows that low self esteem scores were found in student/college students and housewives. In students, a long-term habit of internet surfing might affect their self esteem. In general, the internet addiction rate in early adolescence is mostly in the moderate range, with a percentage of $50 \% .{ }^{14}$ According to Bahrainian et al. (2014), teenagers with low self esteem tend to spend more time on social networking sites than their peers with higher self esteem. ${ }^{15}$ A study by Muda et al. (2015) on body self-perception, 90.5\% of housewives were not satisfied with their body shapes. ${ }^{16}$ This discontentment affects their self esteem, making them more susceptible to low self esteem upon contracting PV that alters their overall appearance.

Table 6 shows that 3 subjects with low self esteem scores resided in Tambaksari, Wonocolo, and outside Surabaya. Tambaksari and Wonocolo residents are mostly in the middle to lower social status. This finding is in accordance with the study by Aunillah and Adiyanti (2015), stating that teenagers in families with low socioeconomic status need support to develop better self esteem. ${ }^{17}$ However, the patients of Dr. Soetomo General Academic Teaching Hospital Surabaya were not evenly distributed from every subdistricts in Surabaya. In general, Dr. Soetomo General
Academic Teaching Hospital Surabaya is a government referral hospital for patients from outside Surabaya with middle to lower social status.

Table 7 shows that low self esteem scores were found in some patients who have been infected for more than 3 months. Paerna et al. (2015) also explained that visible skin lesions and the need for treatment might lead to avoidance of social activities. Consequently, daily interactions with friends and close ones might be affected, impacting one's self esteem and increasing anxiety. ${ }^{18}$

Table 8 shows that low self esteem scores were observed in subjects with lesions on the body/trunk. Also, Salomé et al. (2016) supported that changes in appearance, although in covered areas, might lead to negative feelings, including fear, worry, distress, anger, and self rejection, impacting the patient's self esteem and self image.${ }^{19}$ Table 8 also shows that PV patients with facial site infection had normal self esteem score. This might be due to make up use to conceal the lesion. Make up does not alter skin structure or function, nor its condition; however, its immediate visual effect might help them to restore their self esteem and confidence, which in turn will lead to improvement in general welfare and aid in social sports, educational, and normal occupational activities. ${ }^{20}$

This retrospective study of self esteem assessment of PV patients in the Dermatovenereology outpatient clinic General Hospital Dr. Soetomo Surabaya obtained 90 new PV patients; only 53 of them were eligible. From the 53 subjects, there were more male patients, the teenage/adolescent age group (11-24 years), with basic education level (primary school, middle school), with daily occupation as a student/college student, domiciled in Wonocolo, Tambaksari, and outside Surabaya. The patients of Dermatovenereology outpatient clinic of General Hospital Dr. Soetomo mostly come for treatment after the first month of infection, with the trunk as the most common site. Generally, out of 53 subjects with PV, low self esteem scores were found in 3 subjects (5.7\%); therefore, it can be concluded that the majority of PV patients had normal self esteem scores.

\section{REFERENCES}

1. Noviandini A, Suyoso S, Astari L. Pemeriksaan pewarnaan Kalium Hidroksida $(\mathrm{KOH}) 20 \%+$ tinta ParkerTM Blue-Black, Chicago Sky Blue (CSB), dan kultur jamur pada dermatomikosis superfisialis. BIKKK 2017; 29(1): 1-9.

2. Wulandari P, Arifianto, Aini N. Hubungan obesitas dengan harga diri (self esteem) pada remaja putri SMA negeri 13 Semarang. Jurnal Keperawatan Soedirman 2016; 11(2): 81-9. 
3. Masliah T. Penemuan dini kusta pada anak sekolah dasar. Media Kesehatan Masyarakat Indonesia 2016; 10(4): 205-10.

4. Łakuta P, Marcinkiewicz K, Bergler-Czop B, Brzezińska-Wcisło L. How does stigma affect people with psoriasis?. Advances in Dermatology and Allergology 2017; 34(1): 3641.

5. Szepietowski J, Reich A. Stigmatisation in onychomycosis patients: a population-based study. Mycoses 2009; 52(4): 343-9.

6. Rosenberg, M. Society and the Adolescent SelfImage. Princeton University Press 2015.

7. De Brito MJA, Nahas FX, Barbosa MVJ, Dini GM, Kimura AK, Farah AB, et al. Abdominoplasty and its effect on body image, self esteem, and mental health. Annals of Plastic Surgery 2010; 65(1): 5-10.

8. Nirmalasari L, Masusan K. Self esteem, gender dan prestasi kerja (study pada penyiar radio di kota Bandung). SMART-Study \& Management Research 2014; 11(2): 18-27.

9. Sarandria. Efektifitas Cognitive Behavioural Therapy (CBT) untuk meningkatkan self esteem pada dewasa muda (Tesis). Depok: Universitas Indonesia. 2012.

10. Bos AER, Muris P, Mulkens S, Schaalma HP. Changing self esteem in children and adolescents: a roadmap for future interventions. Netherlands Journal of Psychology 2006; 62(1): 26-33.

11. Orth U, Trzesniewski KH, Robins RW. Self esteem development from young adulthood to old age: a cohort-sequential longitudinal study. Journal of Personality and Social Psychology 2010; 98(4): 645-58.

12. Hampson SE, Edmonds GW, Barckley M, Goldberg LR, Dubanoski JP, Hillier TA. A big five approach to self-regulation: personality traits and health trajectories in the Hawaii longitudinal study of personality and health. Psychology, Health \& Medicine 2015; 21(2): 152-62.

13. Manab A. Memahami regulasi diri: sebuah tinjauan konseptual. In Seminar Asean 2nd Psychology dan Humanity, Psychology Forum UMM 2016; 19-20.

14. Sari AP, Ilyas A, Ifdil I. Tingkat kecanduan internet pada remaja awal. JPPI 2017; 3(2): 110 7.

15. Bahrainian SA, Alizadeh $\mathrm{KH}$, Raeisoon MR, Gorji $\mathrm{OH}$, Khazaee A. Relationship of internet addiction with self esteem and depression in university students. Journal of Preventive Medicine and Hygiene 2014; 55(3): 86-9.

16. Muda W, Kuate D, Jalil R, Nik W, Awang S. Self-perception and quality of life among overweight and obese rural housewives in Kelantan, Malaysia. Health and Quality of Life Outcomes 2015; 13(1): 19-25.

17. Aunillah F, Adiyanti MG. Program pengembangan keterampilan resiliensi untuk meningkatkan self esteem pada remaja. Gadjah Mada Journal of Professional Psychology (GamaJPP) 2015; 1(1): 48-63.

18. Paerna E, Aluoja A, Kingo K. Quality of life and emotional state in chronic skin disease. Acta Dermato-venereologica 2015; 95(3): 312-6.

19. Salomé GM, de Almeida SA, de Jesus Pereira MT, Massahud MR, de Oliveira Moreira CN, de Brito MJA, et al. The impact of venous leg ulcers on body image and self esteem. Advances in Skin \& Wound Care 2016; 29(7): 316-21.

20. Allen E. Skin camouflage can help restore young people's self-confidence. Dermatological Nursing 2015; 14(1): 18-23. 